\title{
UPGRADING SISTEM PENGELOLAAN KEUANGAN DESA BERBASIS STANDAR AKUNTANSI KEUANGAN (SAK) DI DESA NYURLEMBANG NARMADA LOMBOK BARAT
}

\author{
Umu Rosyidah \\ Universitas Islam Negeri Mataram \\ umurosyidah032@gmail.com
}

\begin{abstract}
Abstrak: Pemerintah Desa sebagai pengelola dan pemangku kebijakan di desa harus dapat menyelenggarakan pengelolaan secara profesional, efektif, efisien, dan akuntabel. Pengelolaan juga harus didasarkan pada prinsip-prinsip manajemen publik yang baik agar terhindar dari tindakan yang kurang bermoral seperti penyimpangan, penggelapan, penyelewengan, dan tindakan korup lainnya. Pengelolaan keuangan meliputi kegiatan perencanaan, pelaksanaan, penatausahaan, pelaporan, dan pertanggungjawaban keuangan desa. Secara regulatif semua keuangan desa ini akan terdokumentasi dalam bentuk APBDes yang pengelolaannya mengikuti berbagai petunjuk peraturan perundang-undangan. Ini artinya, pemerintah desa tidak lagi sembarangan mengelola keuangan desa sekalipun otoritas sebagai kuasa pengguna anggaran dan pengguna anggaran ada pada seorang kepala desa. Pengabdian ini bertujuan untuk meningkatkan pengetahuan dan pelaksanaan pembinaan bagi kepala desa dan aparatnya sehingga dapat menambah referensi aparat tentang manajemen atau pengelolaan keuangan desa yang sesuai dengan peraturan yang berlaku yang berstandar akuntansi keuangan. Hasil pengabdian ini adalah pelatihan yang diberikan memberikan manfaat dan kontribusi bagi peningkatan pemahaman dan pengetahuan dalam manajemen pengelolaan dan pelaporan keuangan desa baik secara manual maupun dengan aplikasi TIK dengan aplikasi SIKUDes.
\end{abstract}

Kata Kunci: Sistem Pengelolaan Desa, Standar Akuntansi Keuangan (SAK), SisKeuDes

\begin{abstract}
Administrative village as the manager and stakeholder in the village must be able to carry out management in a professional, effective, efficient and accountable manner. Management must also be based on the principles of good public management to avoid immoral actions such as irregularities, embezzlement, fraud, and other corrupt actions. Financial management includes activities in planning, implementing, administering, reporting, and responsible for village finance. Refering to the law, the finances will be documented in the form of APBDes whose management follows various legislative guidelines. This means that the village government is no longer carelessly managing village finance even though the authority as the power of budget users and budget users is with a village head. This community service program aims to increase the knowledge and implementation of guidance for the village head and his apparatus so that they can add apparatus references about village financial management or management in accordance with applicable regulations that have financial accounting standards. The result of this service is that the training provides benefits and contributes to the improvement of understanding and knowledge in village financial management and reporting management both manually and SIKUDes application.
\end{abstract}

Keywords: Village Management System, Financial Accounting Standards, SisKeuDes

\section{Pendahuluan}

Dengan hadirnya Undang-Undang Nomor 6 Tahun 2014 tentang Desa, maka muncul perhatian yang begitu besar dari beberapa pihak terhadap desa. Hal itu tidak lain karena akibat pemberian dana desa yang jumlahnya makin besar oleh Pemerintah Pusat. Tujuan dari diberlakukannya UU No. 6 tahun 2014 ini adalah sebagai upaya untuk meningkatkan kesejahteraan dan pembangunan desa yang lebih merata melalui perbaikan fungsi desa dalam hal pelayanan publik, 
pemberdayaan perekonomian desa, serta pembinaan kemasyarakatan desa dan pemberdayaan masyarakat desa. Pemerintah Desa yang sebelumnya hanya berperan sebagai pelaksana kebijakan Pemerintah Daerah, kini dituntut untuk mampu menyelenggarakan pembangunan desanya sendiri serta mendorong masyarakatnya untuk ikut serta berperan aktif dalam pembangunan.

Sebagai penyelenggara, pemerintah desa tidak hanya mengelola dana desa yang bersumber dari APBN, pemerintah desa juga mengelola Alokasi Dana Desa (ADD), Bagi Hasil Pajak dan Retribusi Daerah, Bantuan Keuangan Provinsi serta pendapatan asli desa (PADes). Secara regulatif semua keuangan desa ini akan terdokumentasi dalam bentuk APBDes yang pengelolaannya mengikuti berbagai petunjuk peraturan perundang-undangan. Ini artinya, pemerintah desa tidak lagi sembarangan mengelola keuangan desa sekalipun otoritas sebagai kuasa pengguna anggaran dan pengguna anggaran ada pada seorang kepala desa.

Dalam hal pengelolaan dana desa, akan ada risiko terjadinya kesalahan baik bersifat administratif maupun substantif yang dapat mengakibatkan terjadinya permasalahan hukum mengingat belum memadainya kompetensi kepala desa dan aparat desa dalam hal penatausahaan, pelaporan, dan pertanggungjawaban keuangan desa (BPKP, 2015). ${ }^{1} \mathrm{Hal}$ itu terjadi karena pemerintahan desa yang akan mendapatkan pendanaan program dan kegiatan dari berbagai sumber (APBN dan APBD Provinsi/Kabupaten) mengandung konsekuensi harus mampu mengelola secara transparan, akuntabel, dan bebas dari penyalahgunaan. Pemerintah Desa sebagai pengelola dan pemangku kebijakan di desa harus dapat menyelenggarakan pengelolaan secara profesional, efektif dan efisien, serta akuntabel yang didasarkan pada prinsip-prinsip manajemen publik yang baik agar terhindarkan dari tindakan yang kurang bermoral seperti penyimpangan, penggelapan, penyelewengan, dan tindakan korup lainnya.

Pengelolaan keuangan meliputi kegiatan perencanaan, pelaksanaan, penatausahaan, pelaporan, dan pertanggungjawaban keuangan desa². Secara regulatif semua keuangan desa ini akan terdokumentasi dalam bentuk APBDes yang pengelolaannya mengikuti berbagai petunjuk peraturan perundang-undangan. Ini artinya, pemerintah desa tidak lagi sembarangan mengelola keuangan desa sekalipun otoritas sebagai kuasa pengguna anggaran dan pengguna anggaran ada pada seorang kepala desa. Kondisi aparatur pemerintah daerah saat ini kemampuannya masih rendah, terutama dalam hal pengelolaan keuangan daerah. ${ }^{3}$

Pada tataran pertanggungjawaban pengelolaan administrasi keuangan, kompetensi sumber daya manusia di desa merupakan kendala utama ${ }^{4}$. Kapasitas sumber daya manusia di desa selama ini kurang merata ${ }^{5}$. Kementerian keuangan juga menilai perangkat desa masih belum siap untuk menerima anggaran dana desa saat ini ${ }^{6}$. Terdapat masalah kapasitas

\footnotetext{
${ }^{1}$ Badan Pengawasan Keuangan dan Pembangunan Republik Indonesia. Pedoman pengelolaan keuangan desa. (Palembang: BPKP, 2015)

2 PP nomor 58 Tahun 2005 tentang Pengelolaan Keuangan Daerah

3 Sidik, M. Optimalisasi pajak daerah dan restribusi daerah dalam rangka meningkatkan kemampuan keuangan daerah. Makalah disampaikan pada acara orasi ilmiah di Bandung. 2002

${ }^{4}$ Subroto, A. Akuntabilitas pengelolaan dana desa (Studi kasus pengelolaan alokasi dana desa di desa-desa dalam wilayah Kecamatan Tlogomulyo Kabupaten Temanggung tahun 2008). Tesis. (Semarang: Universitas Diponegoro, 2009

5 Yuliana, M. Desa kini dan masa depan dalam sudut pandang sisi dilematis UUDesa. 2013 Available at https://www.academia.edu.

${ }^{6}$ Basri, C. Desa belum siap kelola dana desa yang besar. Kementerian Keuangan Republik Indonesia, Jakarta Tahun 2014 Available at http://www.kemenkeu.go.id
} 
administrasi dan tata kelola aparat belum mampu menciptakan perubahan yang signifikan terhadap kemajuan dan kesejahteraan di desa.

Dalam hal pengelolaan keuangan, Desa Nyurlembang pernah mendapatkan pelatihan pengeloaan keuangan desa dari kementerian keuangan namun belum cukup membuat para aparatur desa di Nyurlembang untuk memahami manajemen pengelolaan keuangan desa. Persoalan terkait lainnya adalah ketidakmampuan membuat laporan keuangan yang berstandar akuntansi keuangan sesuai dengan amanah undang - undang yang ada.

Hasil observasi awal menunjukkan bahwa kendala-kendala tersebut disebabkan oleh beberapa hal berikut:

1. Intensitas dan tehnik pelatihan atau pendampingan yang belum optimal

2. Tingkat pendidikan dan latar belakang keilmuan aparatur desa juga mempengaruhi kemampuan dan pemahaman mereka dalam system pengelolan keuangan, sehingga membutuhkan tambahan waktu dan tehnik pendampingan di Desa Nyurlembang

Terkait dengan hal diatas secara regulatif semua keuangan desa pengelolaannya mengikuti berbagai petunjuk peraturan perundang-undangan. Ini artinya, pemerintah desa di Indonesia dan termasuk Desa Nyurlembang harus mampu melakukan pengelolaan keuangan desa yang sesuai dengan standar akuntansi keuangan (SAK).

Kondisi aparatur pemerintah di Desa Nyurlembang saat ini kemampuannya masih belum optimal dalam hal pengelolaan keuangan desa, terutama terkait pada tataran pertanggungjawaban pengelolaan administrasi keuangan. Kompetensi sumber daya manusia di Desa Nyurlembang merupakan kendala utama. Desa Nyurlembang Pernah mendapatkan pelatihan tentang manajemen pengelolaan keuangan yang dilaksanakan oleh kementerian keuangan sehingga perlu dilanjutkan untuk lebih mendetailkan secara operasional. Desa Nyurlembang merupakan salah satu wilayah atau desa dari 16 desa di kecamatan Narmada yang menjadi kecamatan binaan LP2M IAIN mataram, sehingga akan lebih memudahkan untuk melakukan kerjasama dalam pendampingan. Adapun rumusan masalah dalam kegiatan ini adalah Bagaimana strategi dan langkah-langkah kegiatan upgrading sistem pengelolan keuangan desa sesuai standar akuntansi keuangan (SAK) di desa nyurlembang lombok barat?

Kegiatan ini bertujuan Kegiatan pengabdian di Desa Nyurlembang dimaksudkan untuk meningkatkan pengetahuan dan pelaksanaan pembinaan bagi kepala desa dan aparatnya sehingga dapat menambah referensi aparat tentang manajemen atau pengelolaan keuangan desa yang sesuai dengan peraturan yang berlaku yang berstandar akuntansi keuangan.

\section{Metode}

Metode dan strategi pemecahan masalah dalam kegiatan pengabdian pada masyarakat di Desa Nyurlembang sangat terkait dengan alur berfikir tentang masalah yang dihadapi oleh lembaga atau masyarakat dimana dilaksanakan kegiatan pengabdian ini. Maksudnya adalah bahwa pemecahan masalah merupakan cerminan dari rangkaian atau alur berfikir tentang faktor yang menjadi dasar dilakukan suatu kegiatan, apa yang harus dilakukan, bagaimana suatu kegiatan dilakukan dan untuk apa suatu kegiatan harus dilakukan. 
Kerangka pemecahan masalah dapat diilustrasikan dengan gambar 1 berikut ini:

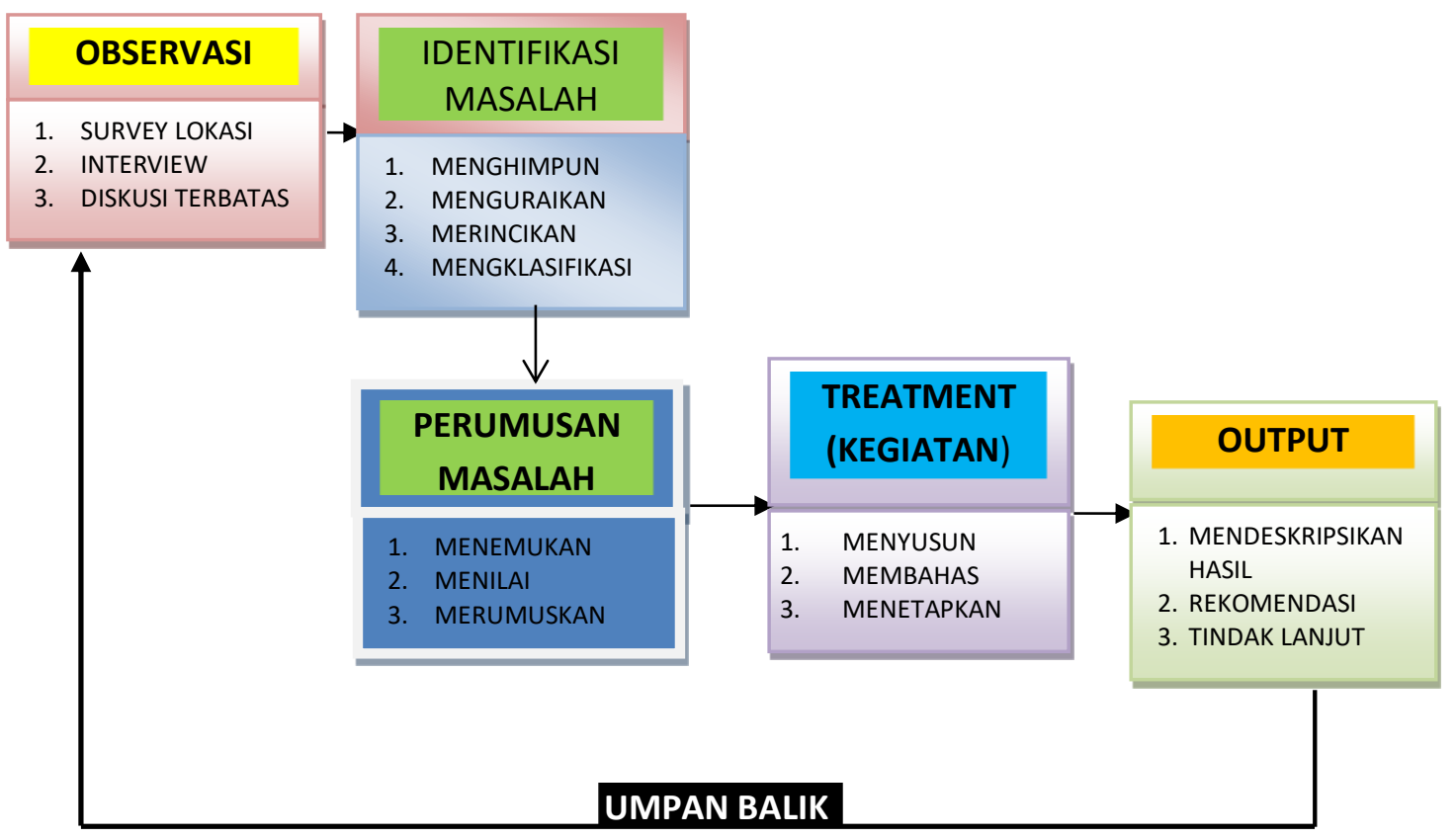

Gambar 1. Kerangka Pemecahan Masalah

Kegiatan upgrading sistem pengelolan keuangan desa Berbasis standar akuntansi keuangan (SAK) yang dilakukan di Desa Nyurlembang didasarkan atas beberapa hal yaitu diantaranya adanya:

1. Pandangan-pandangan umum tentang kerumitan-kerumitan yang muncul dalam implementasi undang-undang Alokasi Dana desa mulai dari perencanaan, pengalokasian dan pelaporan keuangan sebagai bentuk pertanggungjawaban kepala desa dalam pemanfaatan dana desa.

2. Pandangan pandangan umum tersebut konsisten dengan fakta dilapangan bahwa pengelolaan dana desa membutuhkan kehati-hatian, ketelitian dan keprofesionalan pihak aparat desa dan staf sebagai penerima dana.

Atas dasar kondisi diatas, maka telah dilaksanakan kegiatan yang bertujuan untuk mengurangi kesenjangan atau masalah yang dihadapi terkait dengan mekanisme pengelolaan keuangan dan sistem pelaporan yang standar.

\section{Hasil dan Pembahasan}

Kegiatan tersebut dilaksanakan selama 2 hari yaitu sabtu, 02 september - 03 september 2017 dengan durasi waktu inti selama 4 jam per hari atau 8 jam selama 2 hari. Kegiatan tersebut berjalan dengan lancar dengan 2 tema besar yaitu Pemahaman dan implementasi Sistem Informasi Keuangan Desa (SIKUdes). Seluruh peserta yang diundang mengikuti acara sampai selesai selama dua hari. Para peserta pelatihan adalah kepala desa Nyurlembang, Semua staf desa, ketua BUMDes desa nyurlembang, bendahara desa dan peserta tamu dari desa terdekat dengan Nyurlembang yaitu dari desa Gerimak Indah, Lembuak dan Selat. 
Dengan mempertimbangkan sumber daya yang ada, baik tenaga, biaya, waktu yang disesuaikan dengan tugas wewenang dan tanggung-jawab, maka ditetapkan alternatif upgrading sistem pengelolaan keuangan desa Berbasis standar akuntansi keuangan (SAK) dengan bekerjasama antara P2M IAIN Mataram Dengan Pemerintahan Desa Nyurlembang sebagai berikut :

\section{Meningkatkan Pemahaman Tentang SisKeuDes.}

Kegiatan ini bertujuan memberi gambaran bagi kepala desa dan staf terkait dalam mengakses sumber-sumber informasi terkait tentang ADD dan system pelaporan keuangan dan dengan para tehnisi atau tenaga konsultan yang memiliki keahlian atau pemahaman tentang pembuatan laporan keuangan keuangan desa dengan aplikasi SIKUdes.

Dari pemaparan materi tentang SIKUDes, dapat disarikan tentang gambaran umum seputar materi tersebut sebagaimana berikut ini:

a. Untuk mewujudkan pengelolaan keuangan desa yang transparan, partisipatif, akuntabel, tertib dan disiplin anggaran, salah satu faktor yang perlu kita pertimbangkan adalah adopsi Teknologi Informasi Dan Komunikasi (TIK) ke dalam sistem tata kelola keuangan desa. Hal ini karena kita sadari bersama bahwa saat ini TIK sudah sedemikian maju dan canggih. Dengan kecanggihannya, TIK mampu mengelola dan mengolah data dalam jumlah banyak dalam waktu yang singkat dengan hasil yang akurat serta menggunakan sumber daya minimal.

b. Terkait dengan usaha untuk mendorong percepatan terwujudnya tata kelola keuangan desa yang transparan, partisipatif, akuntabel, serta tertib dan disiplin anggaran melalui penerapan TIK dalam bentuk aplikasi, maka Kemendagri melalui Ditjen Bina Pemerintahan Desa telah menjalin kerjasama dengan Badan Pengawasan Keuangan dan Pembangunan (BPKP) sebagaimana tertuang dalam Nota Kesepahaman yang ditandatangani oleh Bapak Menteri Dalam Negeri dan Kepala BPKP pada tanggal 6 November 2015. Kerjasama ini telah menghasilkan suatu sistem aplikasi pengelolaan keuangan desa yang kita beri nama Sistem Informasi Keuangan Desa (SisKeuDes).

c. Aplikasi ini disusun dengan mengacu pada Permendagri Nomor 113 Tahun 2014 Tentang Pengelolaan Keuangan Desa, dan telah disusun sedemikian rupa dan sesederhana mungkin dengan mempertimbangkan dukungan spesifikasi komputer dan kapasitas aparatur desa yang beragam. Sehingga aplikasi ini sangat mungkin untuk diterapkan di masing-masing desa di seluruh Indonesia. Aplikasi ini juga sudah disusun dengan mempertimbangkan keterkaitan antar dokumen perencanaan mulai dari RPJMDesa, RKPDesa serta APBDesa. Di samping itu aplikasi ini juga memungkinkan pengelola keuangan desa khususnya sekretaris dan bendahara melakukan penatausahaan APBDesa secara efektif dan efisien.

d. Dengan disahkan UU No 6 Tahun 2014 tentang Desa, desa diberikan kesempatan yang besar untuk mengurus tata pemerintahannya sendiri serta pelaksanaan pembangunan untuk meningkatkan kesejahteraan dan kualitas hidup masyarakat desa. Selain itu pemerintah desa diharapkan untuk lebih mandiri dalam mengelola pemerintahan dan berbagai sumber daya alam yang dimiliki, termasuk didalamnya pengelolaan keuangan dan kekayaan milik desa. Penyelenggaraan pemerintah desa harus dapat dipertanggungjawabkan kepada masyarakat sesuai ketentuan yang berlaku. 
e. BPKP selaku pengemban amanat untuk mempercepat peningkatan akuntabilitas keuangan negara sebagaimana tercantum dalam diktum Keempat Inpres Nomor 4 Tahun 2011, mengembangkan system aplikasi tata kelola keuangan desa yang dapat digunakan membantu pemerintahan desa dalam melakukan pengelolaan keuangan desa.

f. Sebagai bentuk untuk merealisasikan aplikasi SisKeuDes dan system pelaporan keuangan yang standar di desa Nyurlembang dan juga desa desa lainnya, maka diperlukan kerjasama dengan semua pihak yang memiliki kopetensi sperti pemerintah daerah, LSM, Konsultan dan akademisi serta pihak lainnya Sesuai dengan Peraturan Presiden Nomor 192 Tahun 2014, BPKP telah diberi mandat untuk mengawal akuntabilitas keuangan dan pembangunan nasional, termasuk akuntabilitas pengelolaan keuangan desa.

Berikut merupakan alur implementasi SisKeuDes.

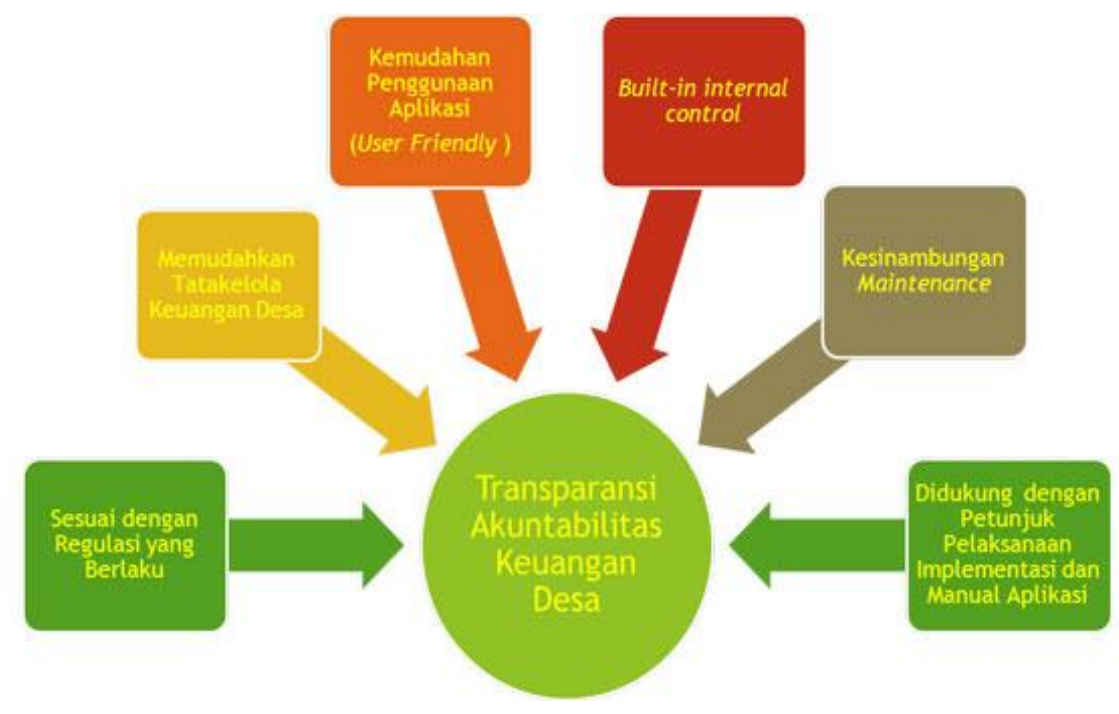

Gambar 2. Kerangka Pemecahan Masalah

\section{Pelatihan Sistem Pelaporan Keuangan Berstandar SAK}

Pelatihan tentang system pelaporan keuangan yang berstandar SAK adalah ditujukan untuk memahamkan para peserta tentang pembuatan laporan keuangan non aplikasi sebagaimana SisKeuDes, karena itu dalam pelatihan ini banyak dipaparkan tentang filosofi dasar tentang prinsip prinsip keuangan dan bentuk laporan keuangan itu sendiri. Materi tentang system pelaporan keuangan desa yang berstandar SAK dapat disarikan sebagai berikut:

a. Untuk sistem informasi secara umum sudah diatur oleh UU no.6/2014 tentang Desa tersebut pada pasal 86 yang berjudul "Sistem Informasi Pembangunan Desa dan Pembangunan Kawasan Perdesaan". Sistem informasi desa ini meliputi data Desa, data Pembangunan Desa, Kawasan Perdesaan, serta informasi lain yang berkaitan dengan Pembangunan Desa dan pembangunan Kawasan Pedesaan. Tanggung-jawab pengembangan sistem informasi desa ini diserahkan kepada Pemerintah Kabupaten/kota. Informasi yang dikelola dalam sistem tersebut adalah informasi umum yang cenderung lebih luas dan berbeda-beda ragamnya antar kabupaten, sesuai dengan perbedaan fokus pembangunan di daerah masing-masing. Sedangkan pembahasan sistem informasi akuntansi adalah spesifik dan mempunyai standar yang sama pada seluruh desa di 
Indonesia seperti masa sebelumnya diatur oleh Permendagri No.37/2007 tentang Pedoman Pengelolaan Keuangan Desa. Karena itu pengembangan sistem informasi akuntansi yang saya usulkan disini dilakukan pada beberapa bagian, ada yang di pusat, ada yang di pemerintah daerah, dan ada yang di desa itu sendiri yang semuanya memanfaatkan jaringan komunikasi data selular dengan tujuan keseragaman sistem dan memperkecil biaya investasi perangkat keras.

b. Dalam bidang akuntansi, Pemerintah sendiri khususnya di Pemda Tk.1 dan Pemda Tk.2 masih belum tuntas dalam merevisi proses akuntansinya agar dapat menghasilkan laporan keuangan berbasis akrual seperti yang diharapkan oleh PP No. 71/2010 Tentang Standar Akuntansi Pemerintah (SAP). PP tersebut mengatur tentang perubahan standar akuntansi dari yang sebelumnya akuntansi berbasis kas menjadi berbasis akrual. Saat ini masih diberlakukan peraturan transisi yang disebut Standar Akuntansi Pemerintahan berbasis Kas menuju Akrual. Nah kalau Pemerintahnya sendiri memerlukan waktu selama 4 tahun (sejak 2010) dan belum menuntaskan transisi laporan keuangan berbasis kas menjadi berbasis akrual, bagaimana nantinya kira-kira proses akuntansi yang harus dilakukan oleh ke 78 ribu desa yang umumnya memiliki sumberdaya manusia yang lebih terbatas.

c. Berdasarkan informasi yang penulis dapat, saat ini masih berlaku Peraturan Menteri Dalam Negeri No.37/2007 tentang Pedoman Pengelolaan Keuangan Desa yang menjadi peraturan pelaksana dari UU No.32/2004 tentang Pemerintahan Daerah. Dalam Permendagri tersebut disebutkan bahwa pengelolaan keuangan desa dilaksanakan oleh perangkat desa antara lain, Bendahara Desa dan Pelaksana Teknis Pengelolaan Keuangan Desa (PTPKD). Sedangkan dokumen yang disebutkan dalam Permendagri yang harus digunakan dalam pengelolaan keuangan desa tersebut adalah:

1) Buku kas umum;

2) Buku kas pembantu perincian obyek penerimaan;

3) Buku kas pembantu perincian obyek pengeluaran;

4) Buku kas harian pembantu.

d. Dengan pemahaman atas situasi dan kondisi dari pengelolaan keuangan desa saat ini, kita dihadapkan pada fakta bahwa dalam waktu dekat pencairan dana desa akan segera dilaksanakan. Bagaimana kesiapan aparat, prosedur dan alat bantu pengelolaan keuangan di tingkat desa kedepannya.

e. Di satu sisi Desa diberi tugas untuk menyelenggarakan urusan pemerintahan sehingga untuk pencatatan dan pertanggung-jawaban pengelolaan keuangannya seharusnya mengikuti standar akuntansi yang dikeluarkan pemerintah yang telah diatur dalam PP no.71/2010. Namun di sisi lain seperti yang diungkapkan Robert Endi Jaweng dalam diskusi " Prospek Implementasi UU No. 6/2014", terdapat masalah kapasitas administrasi dan tata kelola aparat pemerintah desa yang masih minim. Kemudian sistem akuntabilitas dan pranata pengawasan yang masih lemah, termasuk belum kritisnya masyarakat atas pengelolaan anggaran pendapatan dan belanja desa.

f. Penyusunan PP tentang akuntansi dan pelaporan laporan keuangan desa harus dirangkai secara amat hati-hati. Diduga seluruh desa amat terbelakang dalam teknologi akuntansi, 
sebagian diramalkan cepat beradaptasi, sebagian lagi amat sulit beradaptasi dengan teknologi akuntansi. Diramalkan akan ada berbagai desa menerapkan akuntansi pemerintahan karena dinilai bermanfaat bagi desa yang bersangkutan namun jumlahnya amat terbatas. Karena itulah kita harus coba untuk menemukan solusi-nya dari sisi sumberdaya manusia dan perangkat pendukung (aplikasi akuntansi).

\section{Kesimpulan}

Berdasarkan hasil kegiatan pengabdian dan pembahasannya, maka kesimpulan pengabdian ini adalah:

1. Mengelola keuangan desa tidak hanya mengandalkan kuasa kepala desa dan perangkatnya. Tetapi butuh keterlibatan berbagai stakeholders yang ada di desa. Apalagi saat ini desa telah mengelola dana dalam jumlah besar. Untuk itu, desa perlu memiliki orang yang mahir agar membantu menyusun RPJMDes, RKPDes, Design \& RAB serta APBDes.

2. Tidak ada anggaran untuk membiayai penyusunan Design dan RAB. Selain itu, insentif untuk Tim Pelaksana Teknis Pengelolaan Keuangan Desa (PTPKD) juga tidak ada, termasuk TPK Desa. Padahal mereka adalah para pelaksana teknis. Sukses tidaknya pengelolaan keuangan desa terletak pada kontribusi mereka. Pengabaian atas jasa mereka bisa saja jadi masalah bagi pemerintah desa itu sendiri.

3. Bahwa good will dan political will pemerintah dengan menghadirkan regulasi khusus tentang desa sampai saat ini tidak cukup membantu kepala desa dan perangkatnya.

\section{Referensi}

Badan Pengawasan Keuangan dan Pembangunan Republik Indonesia. Pedoman pengelolaan keuangan desa. (Palembang: BPKP, 2015)

Mulyadi, System Akuntansi, Edisi Ketiga, (Jakarta: Salemba empat), 2001

Haryanto, Sahmuddin, dan Arifuddin, Akuntansi Sektor Publik. Edisi Pertama, (Semarang: Universitas Diponegoro, 2007)

Kaho, Yosef Riwu, Prospek Otonomi Daerah Di Negara Republik Indonesia, (Jakarta : PT. Gravindo Persada, 1997)

Sulistiyani, Ambar Teguh, Kemitraan dan Model-Model Pemberdayaan, (Yogyakarta : Gava Media, 2004)

PP nomor 58 Tahun 2005 tentang Pengelolaan Keuangan Daerah

Aliyah, S. dan A. Nahar, Pengaruh Penyajian Laporan Keuangan Daerah Dan Aksesibilitas Laporan Keuangan Daerah Terhadap Transparansi Dan Akuntabilitas pengelolaan Keuangan Daerah Kabupaten Jepara, Jurnal Akuntansi dan Auiditing, Vol. 8 No. 2 , 2012

Subroto, A. Akuntabilitas pengelolaan dana desa (studi kasus pengelolaan alokasi dana desa di desadesa dalam wilayah Kecamatan Tlogomulyo Kabupaten Temanggung tahun 2008). Thesis. (Semarang: Universitas Diponegoro, 2009

Sidik, M. Optimalisasi pajak daerah dan restribusi daerah dalam rangka meningkatkan kemampuan keuangan daerah. Makalah disampaikan pada acara orasi ilmiah di Bandung. 2002

Yuliana, M. Desa kini dan masa depan dalam sudut pandang sisi dilematis UUDesa. 2013 Available at https://www.academia.edu.

Basri, C. Desa belum siap kelola dana desa yang besar. Kementerian Keuangan Republik Indonesia, Jakarta Tahun 2014 Available at http://www.kemenkeu.go.id 